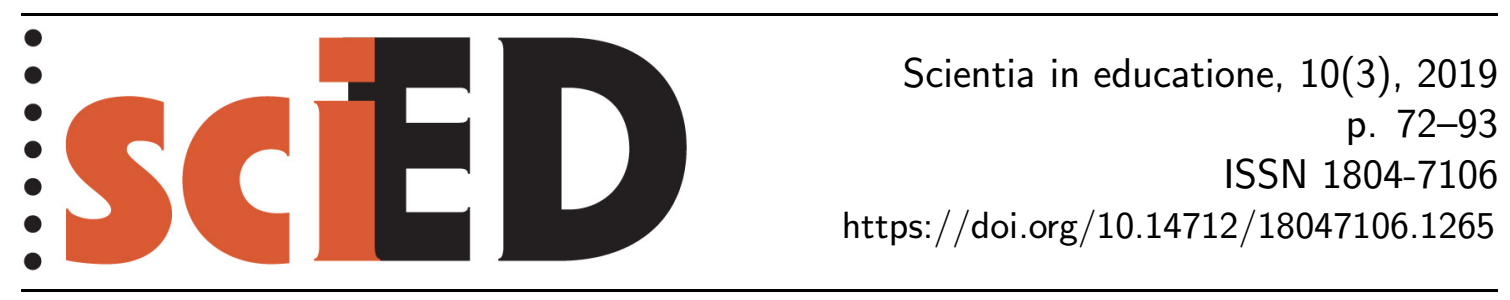

\title{
Geology at the Lower Secondary Educational Level (ISCED 2): Comparison of the Czech Republic, Estonia, Slovenia and Poland
}

\author{
Tereza Jedličková, Andrea Svobodová, Václav Kachlík
}

\begin{abstract}
Geology is a science with a highly interdisciplinary character. Thus, in education it is ideal to provide education in a form integrated with the other branches of natural sciences under the subject of Science or Natural Sciences. However, most European countries prefer separate teaching of the individual educational fields and subsume geology within one of them, most frequently biology or geography. The submitted study discusses the potential advantages and disadvantages of various strategies of allocation of geological topics in education. A comparative method is used to evaluate and analyse curricular documents in the Czech Republic, Estonia, Slovenia and Poland at the lower secondary educational level. The comparison is focused on the scope and incorporation of selected educational content of geology into individual educational subjects, and on the recommended teaching methods suitable for interpreting geological subject matter. On the basis of this knowledge from abroad, individual subjects are selected for the "best practice" and subsequently proposed for implementation under the conditions in the Czech Republic. This seeks to make geology more familiar and attractive for students at the lower secondary level of education.
\end{abstract}

Key words: geology education, educational content of geology, curricular documents, lower secondary education, comparative study.

\section{Výuka geologie v rámci nižšího sekundárního stupně vzdělávání (ISCED 2): Komparace České republiky, Estonska, Slovinska a Polska}

\begin{abstract}
Abstrakt
Geologie je věda vysoce interdisciplinárního charakteru. Ve vzdělávání by se tedy ideálně nabízelo vyučovat ji integrovaně s ostatními př́rodovědnými obory v rámci předmětu Science, resp. Přírodní vědy. Většina evropských států však preferuje separovanou výuku jednotlivých oborů a geologické učivo přiřazuje $\mathrm{k}$ jednomu $\mathrm{z}$ nich, nejčastěji biologii nebo geografii. Předložená studie diskutuje možné výhody a nevýhody různých strategií zařazení učiva geologie do výuky. Komparativní metodou hodnotí a analyzuje kurikulární dokumenty Ceské republiky, Estonska, Slovinska a Polska na úrovni nižšího sekundárního
\end{abstract}


vzdělávání. Předmětem komparace jsou kromě rozdílných strategií zařazení geologického učiva do výuky také rozsah a začlenění vybraného vzdělávacího obsahu z oblasti geologie do jednotlivých vyučovacích předmětů a doporučené výukové metody vhodné pro interpretaci geologického učiva. Na základě těchto zahraničních poznatků jsou vybrány konkrétní náměty „nejlepší praxe“ a následně navrženy pro implementaci do podmínek Ceské republiky se záměrem přiblížit a zatraktivnit geologii žákům druhého stupně základních škol.

Klíčová slova: výuka geologie, geologické učivo, kurikulární dokumenty, nižší sekundární vzdělávání, komparativní studie.

\section{INCLUSION OF GEOLOGICAL SUBJECT MATTER IN EDUCATION}

The natural sciences traditionally include the fields of Biology, Chemistry, Physics, Geography and Geology. While the first four have a traditional position in teaching at the elementary and secondary levels in the Czech Republic, in the past Geology did not generally have such a fixed position as the other above-named fields (Jeníková, 2017). Conditions are similar in most of the countries of Europe and Geology is not taught as a separate subject in secondary education (Fermeli et al., 2011). Nonetheless, geology is widely considered to be an important part of general education and its practical importance for the development of human society dates back to ancient times. The significance of the geological sciences has been increasingly emphasised since the $18^{\text {th }}$ century, especially as a result of the demand for raw materials (coal and iron, later petroleum and gas), and continues at the present time because of the related negative impact on the natural environment. Study of natural archives can substantially contribute to reducing the risk connected with natural and anthropogenic hazards in the future.

In the absence of fundamental knowledge about the functioning of the Earth as a planet, human society cannot live for long in equilibrium with the natural environment. Consequently, teaching of geology is essential at all levels of education, in close connection with the other fields of the natural sciences. Geology is a very interdisciplinary science, where the synergic effect of interconnected teaching of the natural sciences can greatly contribute to understanding geological processes. Simultaneously, the physical and chemical nature of these processes can contribute to practical teaching in the other fields of the natural sciences.

The inclusion of Geology in educational programs for primary and secondary education must be considered to be the first step towards improving teaching of the natural sciences (Pluskalová, 2004). The secondary role assigned to geology leads to global concern in the geological community is based on the substantial reduction in the geological syllabi. This fact is leading to a decrease in number of students of geology at universities (Fermeli et al., 2011). In addition, international surveys suggest that students are frequently not capable of adequately understanding the basic facts and concepts of the natural sciences, including understanding geological processes in a broader context (Meléndez et al., 2007). 
Three basic approaches are generally used for teaching geology at the lower secondary educational level in the countries of Europe. The most frequent curriculum involves the inclusion of geological content in the subjects of Biology and Geography. Selected geological topics can also be taught in the context of subjects such as Chemistry or Physics; nonetheless, this does not generally entail a comprehensive explication of the geological subject matter. Geology education can also take place within the integrated subject of Science. Higher secondary education further offers a third form of teaching Geology, as an independent subject (this model is not very widespread in the Czech Republic). In most European countries, a comprehensive conception of teaching the Earth Sciences is frequently completely lacking or is incorporated to a limited degree into other related disciplines. The inclusion of geology into other conceptually related subjects assigns geology to an inferior position. Chapters on geology are frequently ignored or explained only vaguely (Meléndez et al., 2007; Fermeli et al., 2011). Surveys carried out in England and Wales have shown that educators teaching the Earth Sciences are usually biologists, chemists or physicists (King, 2004). Information obtained from teachers has revealed that their basic geological knowledge is, in general, poor and inadequate. Most teachers stated that they would require greater educational support in this area (King, 2001).

It is anticipated that an integrated approach will lead to greater student motivation and greater interconnection of the subject matter with everyday life (Wake, 2008). From an organisational point of view, integrated teaching should lead to saving time, as it would avoid undesirable duplication of the educational content (Hejnová, 2011). However, Pluskalová (2004) points out that the integration of subjects at the level of complex fields of education (e.g. Biology with Geology) is a very demanding process. A basic requirement for implementation of integrated teaching is a teacher who is fully trained in the subjects to be integrated. It follows from an analysis performed by Hejnová (2011) that the introduction of integrated teaching of the natural sciences in Czech schools is prevented particularly by pre-school teacher training. This unfortunate situation is intensified by the lack of a long-term tradition of an integrated approach to teaching and the related lack of confidence of Czech professionals, teachers and the general public towards this form of education.

Although there are a great many theoretical arguments supporting either integrated teaching or teaching the natural sciences as individual subjects, only very little empirical evidence has been presented for their effect on the study results of students (Czerniak, 2014; Lederman \& Niess, 1997). The Czech Republic, Estonia, Slovenia and Poland are countries where the natural sciences at the lower secondary educational level are divided into individual subjects. These are countries of the former eastern bloc that have undergone relatively fundamental reform of their educational systems in the last few years. At the present time, Estonia, Slovenia and Poland have achieved better results in PISA tests of natural science knowledge than the Czech Republic (OECD, 2018). The educational strategy forming a basis for curricular documents could play a key role in this success. The introduction of Geology as an independent teaching subject is lacking in all these countries; nonetheless, the approach to inclusion of geology and the scope of educational content differs in the individual countries. Can the selected tactics of these countries be applied to the Czech educational system? Specifically, which particular approach could contribute to making the teaching of geology more effective and attractive? 


\section{OBJECTIVES AND METHODOLOGY}

This study concentrates on the structure and content of curricular documents in relation to geology (inclusion of geological content, the scope of the subject matter, recommended teaching methods, etc.). Its goal was to perform an extensive analysis and subsequent comparison of selected curricular documents for lower secondary education, ISCED level 2 (UNESCO, 2012), according to which the current educational system is implemented in the Czech Republic, Estonia, Slovenia and Poland. On the basis of this comparison of curricular documents, individual subjects are selected for the "best practice" and subsequently proposed for implementation under the conditions in the Czech Republic.

The Framework Educational Programme for Basic Education (Jeřábek et al., 2017 ) is the fundamental document for the analysis of geology education in the Czech Republic. The National Curriculum for Basic Schools and its Appendix 4 (Ministry of Education and Research, 2014) constituted the basic analysed document for the Estonian educational system. The White Paper on Education in the Republic of Slovenia (Ministry of Education and Sport, 2011) and the relevant annexes were the documents analysed for Slovenia. The Core Curriculum for Pre-school and General Education (Ministry of National Education, 2002) was selected for Poland. While this document was replaced by a newer version in the $2017 / 2018$ school year, the current form of Polish schooling is still affected by the original version, which was used for the analysis.

\subsection{RESEARCH AND COMPARISON OF SELECTED CURRICULAR DOCUMENTS IN RELATION TO GEOLOGY}

The curricular documents of selected countries were first individually subjected to research with emphasis on the teaching and manner of inclusion of a geology content in the relevant country. Further, the scope of the educational content of geology, i.e. the subject matter and expected outcomes, were monitored. The research was also concerned with the means of interpretation of the recommended teaching methods and requirements on the development of specific skills in the field and interconnection of the stipulated learning content with everyday life.

Content analysis was employed for comparing the above-mentioned curricular documents. Selection of the required concepts followed from this research. The study compares the educational content of geology and the organisational aspect of teaching, i.e. the inclusion of geological subject matter, the range of geology content in elementary schools, recommended teaching methods and equipment.

The text of curricular documents was divided up into smaller parts. These were condensed and labelled by formulating codes. Then these codes were grouped into categories (Erlingsson \& Brysiewicz, 2017). The occurrence of two main groups of categories was recorded - specific subject matter and teaching methods (see Tab. 1,2). The category of specific subject matter comprises expected outcomes and otherwise formulated requirements on students that refer to knowledge of the relevant geological content. The category of teaching methods comprises specific activities characteristic for the individual teaching methods. 
Tab. 1: List of categories for analysis of the occurrence of geological content in the curricular documents of selected countries and examples of their interpretation in the text of the relevant documents

\begin{tabular}{|c|c|}
\hline 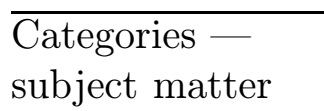 & Examples of interpretation of a particular category \\
\hline The Universe & Solar system, Earth, Moon, stars \\
\hline $\begin{array}{l}\text { The Earth as a } \\
\text { geological body }\end{array}$ & $\begin{array}{l}\text { formation of the Earth, geospheres, the Earth's crust and } \\
\text { mantle }\end{array}$ \\
\hline Mineralogy & $\begin{array}{l}\text { minerals: formation, subdivision of the processes of formation } \\
\text { of minerals, practical importance and use, properties, } \\
\text { identifying samples }\end{array}$ \\
\hline Petrology & $\begin{array}{l}\text { rocks: formation, formation conditions, classification } \\
\text { (magmatic, sedimentary, metamorphosed), practical } \\
\text { importance and use, properties, identifying samples }\end{array}$ \\
\hline $\begin{array}{l}\text { Endogenic } \\
\text { geological } \\
\text { processes }\end{array}$ & $\begin{array}{l}\text { magmatic process, deformation of the lithosphere, causes and } \\
\text { consequences of endogenic processes, formation of the Earth's } \\
\text { surface, lithospheric plates, continental and oceanic } \\
\text { lithospheric/plates, earthquakes, environment of the formation } \\
\text { of magmatic rocks }\end{array}$ \\
\hline $\begin{array}{l}\text { Exogenic } \\
\text { geological } \\
\text { processes }\end{array}$ & $\begin{array}{l}\text { weathering, transport, sedimentation, exogenic factors, causes } \\
\text { and consequences of exogenic processes, shaping of the Earth's } \\
\text { surface, sedimentary basins }\end{array}$ \\
\hline Soils & $\begin{array}{l}\text { formation, composition, properties, development, danger of } \\
\text { devastation }\end{array}$ \\
\hline $\begin{array}{l}\text { Geological } \\
\text { history of the } \\
\text { Earth }\end{array}$ & $\begin{array}{l}\text { geological development, paleontological development, } \\
\text { emergence of life, occurrence of typical organisms, } \\
\text { stratigraphy, geological eras, evolution of organisms, geological } \\
\text { age determination }\end{array}$ \\
\hline $\begin{array}{l}\text { Geological } \\
\text { development and } \\
\text { structure of } \\
\text { territories }\end{array}$ & $\begin{array}{l}\text { for the Czech Republic, e.g. the Bohemian Massif, Western } \\
\text { Carpathians }\end{array}$ \\
\hline $\begin{array}{l}\text { Interactions } \\
\text { between nature } \\
\text { and society }\end{array}$ & $\begin{array}{l}\text { extraordinary events caused by natural forces, natural risks } \\
\text { and catastrophes, causes of occurrence, measures and } \\
\text { protection against natural disasters, basic classification - } \\
\text { geological (earthquakes, volcanic hazards, slope movements), } \\
\text { climatic (tornadoes, hurricanes, etc.), oceanographic (e.g. } \\
\text { tsunamis) }\end{array}$ \\
\hline
\end{tabular}

\subsection{DATA INTERPRETATION}

The first section describes the curricular documents of selected countries individually using a unified structure - a brief introduction into the educational system in each country, the relevant syllabus of geology (focused on lower secondary education) and recommended teaching methods. The following section compares these documents with each other in terms of the aforementioned aspects (inclusion of geology in education, educational content of geology, recommended teaching methods). Specific individual examples of the "best practice" are discussed in the last section and are proposed for implementation under the conditions in the Czech Republic. 
Tab. 2: List of categories for the occurrence of selected teaching methods in curricular documents of the described countries

\begin{tabular}{l|l}
\hline $\begin{array}{l}\text { Categories - } \\
\text { teaching method }\end{array}$ & Examples of interpretation of a particular code \\
\hline Critical thinking & $\begin{array}{l}\text { Critical thinking, assessing information, logical thinking, } \\
\text { argumentation, ability to pose questions }\end{array}$ \\
\hline Research activities & $\begin{array}{l}\text { Teaching oriented towards research, activity teaching, } \\
\text { activation of students }\end{array}$ \\
\hline Wxperimenting & $\begin{array}{l}\text { Experimenting and measuring, observation, formulation and } \\
\text { verification of hypotheses, analysis of results, drawing } \\
\text { conclusions }\end{array}$ \\
\hline information & $\begin{array}{l}\text { Searching for information, critical assessment of the relevance } \\
\text { of information, work with various sources of information }\end{array}$ \\
\hline Group work & Differentiation of teaching, individual approach \\
\hline Digital technology & $\begin{array}{l}\text { Use of modern technology, use of ICT, use of digital } \\
\text { technology, safe work with the internet }\end{array}$ \\
\hline
\end{tabular}

\section{InCLUSiON OF GEOLOGICAL CONTENT IN EDUCATION IN SELECTED EUROPEAN COUNTRIES}

Basic education lasts 9 years in all the evaluated countries (Czech Republic, Estonia, Poland, and Slovenia). The national curriculum of basic education has a central role that overlaps in all the mentioned countries. In a nutshell, it should provide equal support for the mental, physical, social, moral and emotional development of students. The school should contribute to instilling in youth a creative, diverse personality that is capable of self-realisation in a fully-fledged manner in different roles, especially at work, in the family and in public life (Eurydice, 2011). All the described curricula define the expected level of knowledge set for all students at each level of education and differentiate competences which are the aggregates of the relevant knowledge, skills and attitudes. However, the manner of anchoring the subject of Geology in the curriculum differs amongst these countries.

\subsection{National Curriculum of the Czech Republic}

Compulsory school attendance in the Czech Republic is divided into two levels: primary school (grades 1-5, ISCED level 1) and lower secondary school (grades 6-9, ISCED level 2). The Framework Educational Programme for Basic Education delimits the compulsory framework for elementary education and defines the general requirements on the organisation of elementary education. It further sets forth the goals of elementary education, i.e. the creation and gradual development of key competences and provision of a reliable basis for general education. The school level corresponds to school education programs that the schools create themselves and according to which education is provided at the individual schools.

The educational content is divided into nine educational areas. These are formed of one or more fields of education with similar contents. Their educational content is represented by the subject matter and expected outcomes (the compulsory level for formulating outputs in the teaching curriculum in a school educational programme). 


\section{Syllabus of GeOlogy}

The subject matter of Geology and the corresponding expected outcomes permeate both educational levels of primary education. At the primary school level, they occur especially in the educational area of Humans and their World, especially in the units of "The place where we live" and "Diversity of nature" (Jeřábek et al., 2017). From the first level, students should gain basic knowledge related to non-living nature, which should be deepened and expanded at the second level.

At the lower secondary school level, the Czech curriculum assigns geological content to the educational area of Humans and Nature, specifically to the educational field of the Natural Sciences (hereinafter Biology). This encompasses direct definition of the educational content of Non-living Nature, which includes topics such as the Formation and Structure of the Earth, Minerals and Rocks, Internal and External Geological Processes, Soils, Development of the Earth's Crust and Organisms on the Earth, Geological Development and Structure of the Territory of the Czech Republic, Weather and Climate and Extraordinary Events caused by Natural Effects (Jeřábek et al., 2017: p. 75). The other educational fields in the educational area of Humans and Nature are also more or less related to geological subjects. In geography, this applies, e.g., to the subjects of The Earth as a Body in Space, the Landscape Sphere, Training Exercises and Observation in the Terrain of the Local Landscape and Protection of Humans in case of Danger to Health and Life. The teaching field of Chemistry includes subject matter on the Elements, where Inorganic Chemistry encompasses compounds and fuels. The subject unit of the Universe, more precisely the Solar System and the Stars, constitutes learning content that, in the Czech curriculum, permeates three fields of the natural sciences biology, geography and physics.

On the basis of the expected outcomes of Non-living Nature, after completing level 2, students should be able, e.g.

to explain the effect of the individual spheres of the Earth on the formation and continued existence of life, based on their characteristic properties, identify selected minerals and rocks using identification equipment, differentiate among the consequences of internal and external geological processes, including the geological cycle of rocks and the cycle of water, compare the importance of soil-forming agents for the formation of soil, differentiate amongst the main types of soil and kinds of soil in Czech nature (Jeřábek et al., 2017: p. 75).

\section{RECOMMENDED TEACHING METHODS}

Recommended teaching methods are defined in general in the framework of the characteristics of the educational area. The student should gain a comprehensive view of the relationship between humans and nature. The characteristics of this area can lead to the development of critical and logical thinking amongst students. It provides the basis for teaching to progress through activities and by scientific research methods. Through this study, students should learn to use specific recognition methods to acquire skills, such as observation, experimenting and measurement, formulation and verification of hypotheses, analysis of results and drawing the relevant conclusions. The individual fields of education are limited only by their educational content and suitable teaching methods are not defined at this level in the national curriculum. 


\subsection{NATional CURRiculum of Estonia}

In Estonia, compulsory education is divided into three stages: grades 1-3, grades 4-6 (both ISCED level 1) and grades 7-9 (ISCED level 2). The national curriculum defines the results and goals of education for the individual subjects but emphasises mainly the need for development of general competences and abilities that are also applicable outside the field. The schools prepare a school curriculum in accordance with the national curriculum. This consists of a general part and syllabuses for the individual subjects. The choice of teaching methods and materials is left to the schools and individual teachers.

The national curriculum consists of a general part and appendixes. The appendixes set forth subject field syllabuses, optional subject syllabuses and descriptions of cross-curricular topics. The study of geology is part of the compulsory subject field of Natural Science. It is intended to develop competences associated with critical and creative thinking. Science studies should also ensure motivation towards study and shape the student's interest in science and science-related careers. The following subjects comprise the natural science domain: Science (studied from grades 1 to 7), Biology, Geography (both studied from grade 7), Physics and Chemistry (both studied from grade 8).

\section{Syllabus of Geology}

In the Estonian curriculum, a relatively large part of the subject of Geology is assigned to the $2^{\text {nd }}$ stage of study. Specifically, it is included under the subject of Science, which is intended to form a basis for future study of the individual natural sciences. From the viewpoint of geology, after completing grade 6 , students should be acquainted with the basic facts under the subjects of Space, Planet Earth (continents and oceans, natural disasters), Rivers (parts of rivers, water currents), Lakes and Water as a Substance, Landforms and their Shaping, Soils (formation and development) and the Natural Resources of Estonia (minerals, mining and use).

In the $3^{\text {rd }}$ stage, the subject matter of Geology is included in the subject of Geography. The educational content includes the Internal Structure of the Earth, Tectonic Plates and their Movement, Earthquakes, Volcanic Activity, Seismic and Volcanic Areas, Rocks and their Formation. In addition to the subject matter, the expected outcomes are defined very specifically; they correspond to the required educational content with specified geological concepts. For example: The students:

describe tectonic plates according to drawings and maps as well as the geological processes taking place on the edges of tectonic plates: volcanism, earthquakes and the formation and transformation of landforms and rocks; know the reasons for the occurrence of earthquakes and volcanic eruptions, show on a map the main areas where they occur, give examples of their consequences and know how to act in case of danger; explain the erosion of rocks, movement and sedimentation of erosionrelated material and formation of sedimentary and igneous rocks (Ministry of Education and Research, 2014: p. 42).

"Landforms" are another area of geography, which is concerned with geological content. Here, students are acquainted with various shapes of the Earth's surface (mountain ranges and highlands, plains, lowlands, relief of the ocean floor) and also with the progress of evolution of the Earth's surface over time. The separate area 
"Bodies of Water" is devoted to teaching about water as a geological agent. The latter two areas of geography are once more included in the syllabus of this subject in the context of European and Estonian Geographic Location. The content is devoted to regional areas that are identical with the "general" areas, but concentrate on local specific features of the particular phenomena. For example, Estonian Geological Structure and Natural Resources, the Activity of Continental Glaciers in Shaping Landforms in Europe, Problems Related to Groundwater in Estonia, etc.

\section{RECOMMENDED TEACHING METHODS}

Recommended teaching methods are first defined in the characteristics of the educational field of Natural Science. The main goal of teaching geography is to provide students with an overview of processes taking place in nature and society. The material studied should be presented as far as possible in a problem-oriented way and in connection with the students' everyday lives and home areas. The individual specificities of the students should be taken into account. Significant attention is paid to shaping the study motivation of students and various interactive study methods are recommended: problem-based and research-based study, project work, discussions, brainstorming, studies outside the classroom, study visits, etc. Digital technologies and ICT should be used in all the stages of study.

For the individual teaching areas of geography, proposals are made for specific student activities and the use of ICT. In the context of geology, this consists in

describing and comparing rocks (sandstone, limestone, oil shale, coal and granite) and sediments (sand, gravel and clay), compiling an overview or, on the basis of sources of information, presentation of one geological phenomena (earthquake or volcano) or describing an area from a geological angle, studying the erosive and accumulative activities of flowing water in a given river in different sections according to drawings, photos (including satellite photos) and maps (Ministry of Education and Research, 2014: p. 43-45).

Moreover, the introduction to the area of the Natural Science delimits the Options for Integrating Natural Science Subjects and Options for Implementing Cross Curricular Topics.

\subsection{NAtional CURriculum of Slovenia}

In Slovenia, nine years of basic education is divided into three-year cycles: grades 1-3, grades 4-6 and grades 7-9. Slovenia employs a system with a multi-level curriculum. At the national level, it is regulated by the document White Paper on Education in the Republic of Slovenia (Ministry of Education and Sport, 2011), hereinafter the White Paper. This document stipulates compulsory and optional subjects. At the school level, teachers have a certain degree of freedom to adjust the educational content of the subject according to the specific conditions of teaching at the given school. The compulsory subjects set forth in the White Paper must also be part of the curriculum of the school and new teaching subjects cannot be created from them. 


\section{Syllabus of GeOlogy}

In the Slovenian national curriculum, a certain geology content is already included in the integrated subject of Environmental Education (taught in grades 1-3). This consists in basic knowledge about the Universe and Forming of the Earth's Surface.

The educational content of geology is included in the single field of study Geography (taught in grades 6-9). Geology matter is spread out through all the grades and does not have its own separate teaching area. The curriculum defines a number of operational goals for grade 6 . Some of them are concerned with the development of practical skills (e.g. searching for and processing information, assessing its relevance, the use of various means of communication, work in the field, etc.). Another area of operational goals is directly connected to a geological content - students are capable of differentiating the continents, their geographical position and the relationships among them, and they are able to understand the basic laws governing the movement of the Earth in the Universe (Ministry of Education and Sport, 2011: p. 8). The educational content for the $6^{\text {th }}$ grade consists in the size and shape of the Earth, the position of the Earth in the Universe, the oceans and continents, the aquatic environment and surface of the land, movements of the Earth and their consequences.

The remaining geological subjects are taught in the context of the regional geography of the individual continents. In practice, this means, e.g., that teaching about Southern Europe in grade 7 includes the subject of the regional occurrence of earthquakes and volcanic activity and the related operational goals. Amongst these, for example, the student explains the tectonic causes of the occurrence of earthquakes and explains the course of volcanic activity and describes the consequences of volcanic activity and earthquakes for human life (Ministry of Education and Sport, 2011: p. 11). Similarly, teaching in the thematic unit of the Alps or Northern Europe includes glaciers and their impact in forming the surface of the Earth - rivers, river valleys, etc. Teaching in grade 9 is concerned with the region of Slovenia. From a geological standpoint, students are required to explain the main phases in the formation of the present-day relief of Slovenia and the main factors that affected this process (Ministry of Education and Sport, 2011: p. 17).

\section{RECOMMENDED TEACHING METHODS}

Didactic recommendations are generally given for all the compulsory subjects. They provide suggestions for conception of the work of teachers with students. Emphasis is placed on the process of teaching and development of students' skills, their active participation in the educational process and the development of critical thinking. Primarily, teaching methods are emphasised that take into account the individual potential of the student. The Slovenian curriculum brings into equilibrium teaching and other forms of student activities. This part of the syllabus of the subject explains in detail the concept and organisation of geographic excursions.

The White Paper directly contains information on interdisciplinary relationships. These emphasise both the area of the personal development of students (e.g., communication, work with information, reading literacy) and development of their professional skills (e.g. reading graphs, work with modern technologies, ability to defend one's own opinion). 


\subsection{National Curriculum of Poland}

According to the educational system until 2017, compulsory school attendance in Poland included six years of elementary education divided into two stages (szkola podstawowa) and three years at lower secondary school (gimnazjum). The main goal of Polish elementary education, in addition to development of reading and mathematical literacy, also encompasses perfecting the scientific thinking of students. This skill includes the ability to formulate conclusions about nature and society based on observation. The curriculum is also directed towards preparing students for life in a digital society.

The Core Curriculum for Pre-school and General Education stipulates the expected outcomes for the individual subjects. The detailed subject matter is not specified in the Polish curriculum.

\section{Syllabus of GeOlogy}

Teaching progresses in an integrated manner in the first stage of primary education (grades 1-3). The subject matter also includes some geological topics. Geology is taught, e.g. in the educational area of the "Closest Surroundings" (water sources, kinds of surface water, identifying local rocks, soils), the area of Poland and Europe (morphology of the Polish Landscape: high mountains, limestone uplands, lowlands, lakes, ocean), the Earth from Space, Continents and Oceans.

The teaching should grow and expand in a spiral, i.e. in each higher year, information and skills should be repeated, deepened and subsequently expanded. The teaching units and the expected outcomes defined for the separate subject of Nature in the second stage (grades 4-6) correspond to this idea. A number of general goals and the expected outcomes are defined for the subject of Nature. They include, e.g. interest in nature (the student poses questions about phenomena occurring in nature and searches for answers), formulating hypotheses and their verification (the student predicts the course of some phenomena and natural processes, carries out observation and experiments according to instructions), observation measurements and experiments (the student utilises various sources of information and performs measurements, documents and presents the results of observations, uses information and communication technology). These general objectives are identical with the requirements laid down for the related third teaching stage, "gimnazjum". Here, for example, the ability to identify relationships and dependences and explain phenomena and processes, or to formulate of one's own opinions and attitudes are further expanded.

From the viewpoint of teaching geology, Geography is a key subject at secondary schools. The definition of the educational content of this subject more or less corresponds to the teaching units of the subject of Nature (mineralogy, petrology, soils, interaction between humans and nature - see above). However, the expected outcomes are extended to include further subject matter and are at a higher cognitive level than the previous stages. Newly included topics are primarily endogenic and exogenic geology:

the student gives the main characteristics of the lithospheric plates, describes the relationship between the movement of lithospheric plates and the occurrence of volcanic phenomena and earthquakes, understands the effect of wind, erosion, flowing water, ocean waves and glaciers in forming the Earth's surface (Ministry of National Education, 2002: p. 106). 
A newly included subject unit is the "Natural environment in Poland", including important events in the geological history of Poland (the formation of black coal, mountain areas, land flooding events, glaciation, etc.).

\section{RECOMMENDED TEACHING METHODS}

For the subject Nature, the Polish curriculum recommends a choice of activities that would strengthen a scientific approach to the natural sciences and increase interest in nature. Teaching should have an interdisciplinary character and individual subject areas can be taught by teachers in various fields (physics, chemistry, biology, geography).

In teaching geography, it is recommended that the extent of encyclopaedic knowledge be limited in favour of forming the student's ability to use and analyse various kinds of information sources. The concept of requirements in the third stage of education is based on the predominance of regional geography, where students learn general information (including geological subjects) on the basis of study of selected regions. Teaching should be partly practical and implemented with substantial support from experiments, observation, activities in the field and excursions.

\section{COMPARISON OF CURRICULAR DOCUMENTS OF SELECTED COUNTRIES FROM THE VIEWPOINT OF TEACHING GEOLOGY}

\subsection{INCLUSION OF GEOLOGY IN EDUCATION}

In general, it can be stated in the context of elementary education in all the selected countries that geology is part of both educational levels (ISCED level 1, ISCED level 2). However, it is assumed that the subject matter discussed at the first level consists only of a brief acquaintance with a selected subject area and that this will be developed further at the second level. All the analysed countries approach the teaching of the natural sciences in an integrated manner in the context of primary education. At the second level, natural science fields are divided into independent subjects. Geology is not set aside as an independent subject in any of the described curricular documents.

In the Czech Republic, most of the geological subject matter at the second level of elementary schools is included in the subject of Biology, Non-living Nature. Selected topics are also mentioned in other subjects, such as Geography, Chemistry and Physics, where these topics are mostly duplicated - thus they are included both in Biology and, e.g. in Geography. In practice, this means that some topics are taught twice at the second level, in a different subject each time or in a different grade.

Estonia, Slovenia and Poland assign most of the subject matter of geology to the subject of Geography. The specific approach to inclusion of geological subject matter differs in the individual countries. In the Estonian curriculum, some topics (e.g. the Universe) are included in the integrated subject of Science and subsequently are not dealt with in Geography. An independent subject block in the context of Geography, with detailed description of expected outcomes, encompasses the topics of endogenic and exogenic geology. The remaining topics (e.g. rivers, lakes, landscapes) are first 
discussed from a general viewpoint and then in the regional context of the landscapes of Estonia and Europe. Students are able to verify selected general knowledge on the basis of "local" examples. The Polish curriculum has a similar system of ordering of geological subject matter. The individual topics and related expected outcomes are first oriented towards general knowledge. Subsequently, the topics of the natural environment of Poland once again provides the students with scope to connect this theoretical knowledge in practice with local examples (the geological past of Poland, the formation of the Earth's surface, local minerals and rocks). The Slovenian curriculum employs greater inclusion of geological subject matter in Geography. It utilises direct connection of theoretical knowledge with regional examples. For example, endogenic and exogenic geological processes are not taught as independent topics but are discussed in the context of the specific geographic areas with which the relevant process is connected (e.g. the Alps - glacial activity, Southern Europe - volcanic activity and earthquakes). Students receive complex information about the relevant geographic area and acquire general geological knowledge on the basis of specific examples.

\subsection{Educational Content of Geology}

The educational content of the curriculum in the Czech Republic consists of both subject matter and expected outcomes. The subject matter is divided according to the individual topics, which are further specified. This consists basically of a list of concepts that the students should learn during completion of the particular unit. The expected outcomes are related directly to the specific subject matter and are defined rather generally. They concentrate mainly on the knowledge gained by the student rather than on the development of the practical skills of the individual, critical thinking, etc. Although the expected outcomes are compulsory for the individual schools in the Czech Republic, the manner of their formulation leads to knowledge of delimited concepts and does not further expand requirements on the skills of students. As a consequence, emphasis is placed mainly on learning terminology and classification and less on the development of practical skills by students and their ability to think critically, create working hypotheses and evaluate them.

In contrast, the Estonian curriculum delimits the educational content very specifically. For each subject, it sets forth not only the subject matter, but also the related concepts. Learning outcomes are defined quite specifically and in detail. In addition to knowledge of delimited concepts, students are required to have further skills and more complicated cognitive operations following from study of the given subject matter. Compulsory subjects in the Slovenian curriculum have a certain structure, which is maintained for all the subjects. The subject matter is not defined in terms of a list of concepts. The curriculum mentions only individual topics that are related to the general and operational goals of the specific subject. Schools do not have practically any freedom related to assignment of the educational content to the individual subjects; even the names of the individual subjects are specified. Thus integration of the natural science subjects cannot be even considered. The Polish curriculum does not in any way deal with delimitation of specific subject matter. For each subject, general goals are given for the subsequently anticipated outcomes for the individual subject topics. These are rather extensive and are formulated in detail. 


\subsubsection{EXPECTED OUTCOMES}

The expected outcomes are a unit that occur in various forms in all the analysed curricular documents. Tab. 3 gives a comparison of formulation of the expected outcomes for the individual countries. Endogenic geology was selected as a model topic that is contained in all the analysed curricular documents. It is apparent from Tab. 3 that Estonia has the most specific approach to defining the expected outcomes. Poland and Slovenia are at the same level in this respect. All three countries concentrate on processes taking place in the lithosphere and their consequences in terms of volcanic activity and earthquakes. Earthquakes and volcanism are dynamic processes that are most attractive for students but, however, do not encompass further processes at lithospheric plate boundaries. The Czech curriculum mentions only the anticipated output from this topics, which is formulated very generally and briefly. It does not delve into the core of the given subject topics and maintains a definition at the level of "headings". In fact, it doesn't even include the above-mentioned volcanism and earthquakes.

Tab. 3: Comparison of the expected outcomes as defined by selected countries for the model subject of endogenic geology

\begin{tabular}{|c|c|}
\hline \multicolumn{2}{|r|}{ Expected outcomes for the subject of ENDOGENIC GEOLOGY } \\
\hline$\overline{\text { Czech }}$ & Students: \\
\hline Republic & $\begin{array}{l}\text { - differentiate the consequences of internal and external geological } \\
\text { processes, including the rock cycle and hydrological cycle }\end{array}$ \\
\hline Estonia & $\begin{array}{l}\text { Students: } \\
\text { - describe lithospheric plates according to drawings and maps as } \\
\text { well as the geological processes taking place on the boundaries of } \\
\text { lithospheric plates: volcanism, earthquakes and the formation } \\
\text { and transformation of landforms and rocks; } \\
\text { - know the reasons for the occurrence of earthquakes and volcanic } \\
\text { eruptions, show on a map the main areas where they occur, give } \\
\text { examples of their consequences and know how to act in case of } \\
\text { danger; }\end{array}$ \\
\hline Slovenia & $\begin{array}{l}\text { Students: } \\
\text { - explain the tectonic causes of the occurrence of earthquakes and } \\
\text { explain the progress of volcanic activity } \\
\text { - describe the consequences of volcanic activity and earthquakes on } \\
\text { human lives }\end{array}$ \\
\hline Poland & $\begin{array}{l}\text { Students: } \\
\text { - state the main characteristics of lithospheric plates } \\
\text { - describe the relationship between lithospheric plates and the } \\
\text { occurrence of volcanic activity and earthquakes }\end{array}$ \\
\hline
\end{tabular}

The expected outcomes are formulated to different degrees and in various ways; nonetheless, all the countries exhibit little interconnection between the subjects and lack a description of the interconnections among the individual phenomena. For example, the Estonian curriculum speaks about the erosion and accumulation properties of flowing water, but does not mention various means of transporting 
material. Simultaneously, this is an important factor affecting the roundness, shape and size of grains. Extending this subject to include transport would create scope for interconnection of geology with, e.g. physics. Similarly, in the specification of soil, the Czech curriculum does not mention topics such as the origin of soil, soilforming agents, etc. The relationship between the substrate, pedogenic processes, soil forming agents and the resultant soil is not described.

\subsubsection{Selection of GeOlogical Subject matter}

The scope of the educational content was assessed, on the basis not only of the defined subject matter, but also of the requirements on students following from the expected outcomes. The Slovenian and Polish curricula do not even rely on the subject matter in the sense of defined concepts. Tab. 4 compares the assignment of selected geological topics at the lower secondary school level.

Tab. 4: Comparison of the scope of the educational content of geology and inclusion of selected geological topics in the individual subjects at the lower secondary school level in selected countries

$\mathrm{Bi}$ - Biology, Gg - Geography, Sci - Science, Ph - Physics; $\sqrt{ }$ - the curriculum contains this subject matter, $\times$ - the curriculum does not contain this subject matter

\begin{tabular}{l|c|c|c|c}
\hline geology subject matter & $\begin{array}{c}\text { Czech } \\
\text { Republic }\end{array}$ & Estonia & Slovenia & Poland \\
\hline The Universe + formation of the & $\sqrt{ }$ & $\sqrt{ }$ & $\sqrt{ }$ & $\sqrt{ }$ \\
Earth & $\mathrm{Bi}, \mathrm{Ph}, \mathrm{Gg}$ & $\mathrm{Sci}$ & $\mathrm{Gg}$ & $\mathrm{Gg}, \mathrm{Ph}$ \\
\hline The Earth as a geological body & $\sqrt{ }$ & $\sqrt{ }$ & $\sqrt{ }$ & $\sqrt{ }$ \\
& $\mathrm{Bi}, \mathrm{Gg}$ & $\mathrm{Gg}$ & $\mathrm{Gg}$ & $\mathrm{Gg}$ \\
\hline Mineralogy & $\sqrt{ }$ & $\sqrt{ }$ & $\times$ & $\sqrt{ }$ \\
\hline Petrology & $\mathrm{Bi}$ & $\mathrm{Sci}, \mathrm{Gg}$ & & $\mathrm{Sci}, \mathrm{Gg}$ \\
\hline Endogenic geological processes & $\sqrt{ }$ & $\sqrt{ }$ & $\times$ & $\sqrt{ }$ \\
& $\mathrm{Bi}$ & $\mathrm{Gg}$ & & $\mathrm{Sci}, \mathrm{Gg}$ \\
\hline Exogenic geological processes & $\mathrm{Bi}, \mathrm{Gg}$ & $\mathrm{Sci}, \mathrm{Gg}$ & $\mathrm{Gg}$ & $\mathrm{Gg}$ \\
\hline Soils & $\sqrt{ }$ & $\sqrt{ }$ & $\sqrt{ }$ & $\sqrt{ }$ \\
& $\mathrm{Bi}$ & $\mathrm{Sci}, \mathrm{Gg}$ & $\mathrm{Gg}$ & $\mathrm{Gg}$ \\
\hline Geological history of the Earth & $\sqrt{ }$ & $\sqrt{ }$ & $\times$ & $\sqrt{ }$ \\
\hline Geological development and & $\sqrt{ }$ & $\times$ & $\times$ & $\times$ \\
structure of territories & $\sqrt{ }$ & $\sqrt{ }$ & $\times$ & $\sqrt{ }$ \\
\hline Interactions between nature and & $\mathrm{Bi}$ & $\mathrm{Gg}$ & & $\mathrm{Gg}$ \\
society & $\mathrm{Bi}, \mathrm{Gg}$ & $\mathrm{Sci}, \mathrm{Gg}$ & $\mathrm{Gg}$ & $\mathrm{Sci}, \mathrm{Gg}$ \\
\hline
\end{tabular}

Compared to the other countries, the Czech curriculum includes more geological topics. The entire content of non-living nature is assigned to a single subject, making geology teaching comprehensive in the context of lower secondary education. The scope of geological subject matter in the Czech Republic is most similar to that in 
Estonia. In addition, the individual subjects are defined very specifically in terms of the learning content and concepts. The Polish curriculum corresponds to the Estonian curriculum in terms of the number of geological topics but it has less specific content. Slovenia includes geology only sporadically in its curriculum and only in connection with regionally focussed physical geography.

In some cases, it was rather difficult to assess whether the curriculum is actually devoted to this topic. This is especially true of the subject of the Geological History of the Earth, which is contained only in the curriculum of the Czech Republic. Nonetheless, e.g., the Estonian curriculum is related to this area in the integrated subject of Science, where it includes the learning content Development of Life on Earth. Poland encompasses this subject in more detail at the higher level of secondary education. Similarly, a certain part of mineralogy could related to the subject of Chemistry (e.g. in the Czech curriculum). While this is teaching about minerals, it follows from the expected outcome that this subject matter is expounded in terms of chemical properties and not from a geological standpoint (thus the subject of chemistry is not mentioned in the table).

\subsection{RECOMMENDED TEACHING METHODS}

The teaching requirements are more or less the same in all the EU countries. There is a unifying concept in an attempt to develop knowledge and skills that can be used in the everyday lives of students. Requirements on the use of specific teaching methods directed towards attaining this goal are contained to various degrees in the curricular documents of the individual countries. It can be anticipated that teachers will take into consideration especially that part of the curriculum devoted to their teaching field. The presence of requirements on implementation of specific teaching methods was thus assessed at the level of the educational area or the specific field or subject and not on the basis of the characteristics of the curriculum as a whole. In relation to the teaching of geology, there are three ways in which recommended teaching methods could be implemented, i.e. directly in the context of geology, in the context of the characteristics of the subject into which the geology subject matter is included or as the general characteristics of the educational area within which geology is included (see Tab. 5).

The Czech curriculum defines teaching methods only in the framework of the characteristics of the educational area. This is primarily a requirement on the development of critical thinking and managing teaching in an experimental and scientific manner. There is also a brief mention of work with information. The Estonian curriculum requires all the selected methods to be used in teaching (see Tab. 5). Recommended teaching methods are defined both in the characteristics of the educational field of Natural Science and also specifically for the subject of Geography. For the individual areas of teaching, suggestions are given for specific student activities and the use of ICT. The teaching methods employed for the individual subjects in the Slovenian curriculum are partly concerned with teaching standards. The greatest emphasis in the methods is devoted to didactic recommendations for the subject of Geography. They contain suggestions for the use of all the selected teaching methods (see Tab. 5) and also substantiate these working methods in the context of teaching Geography. The Polish curriculum lists basic recommendations for the subject of Geography in the introductory characteristics of the subject. The independent chapter on the Recommended Conditions and Implementation then formulates the main requirements on teaching the individual subjects, including Geography. 
Tab. 5: Comparison of inclusion of recommended methods of geology education, including the place of introduction of the given method

$\sqrt{ }$ - the curriculum mentions this teaching method, $\times$ - the curriculum does not mention this teaching method; Geology - the method is mentioned directly in the context of geology, Subject - the method is mentioned in the context of the characteristics of the subject (within which geology is included), Field - the method is mentioned in the context of the characteristics of the educational area (within which geology is included)

\begin{tabular}{l|c|c|c|c|c|c|c|c}
\hline Teaching method & \multicolumn{2}{|c|}{ Czech Republic } & \multicolumn{2}{|c|}{ Estonia } & \multicolumn{2}{|c|}{ Slovenia } & \multicolumn{2}{|c}{ Poland } \\
\hline Critical thinking & $\sqrt{ }$ & Field & $\sqrt{ }$ & $\begin{array}{c}\text { Field, } \\
\text { Subject }\end{array}$ & $\sqrt{ }$ & Subject & $\sqrt{ }$ & Subject \\
\hline Research activities & $\sqrt{ }$ & Field & $\sqrt{ }$ & $\begin{array}{c}\text { Field, } \\
\text { Subject }\end{array}$ & $\sqrt{ }$ & Subject & $\sqrt{ }$ & Subject \\
\hline Experimenting & $\sqrt{ }$ & Field & $\sqrt{ }$ & $\begin{array}{c}\text { Field, } \\
\text { Geology }\end{array}$ & $\sqrt{ }$ & Subject & $\sqrt{ }$ & Subject \\
\hline $\begin{array}{l}\text { Work with } \\
\text { information }\end{array}$ & $\sqrt{ }$ & Field & $\sqrt{ }$ & $\begin{array}{c}\text { Field, } \\
\text { Subject }\end{array}$ & $\sqrt{ }$ & Subject & $\sqrt{ }$ & Subject \\
\hline Individualisation & $\times$ & $\times$ & $\sqrt{ }$ & $\begin{array}{c}\text { Field, } \\
\text { Subject }\end{array}$ & $\sqrt{ }$ & Subject & $\times$ & $\times$ \\
\hline Group work & $\times$ & $\times$ & $\sqrt{ }$ & Field & $\sqrt{ }$ & Subject & $\times$ & $\times$ \\
\hline Digital technology & $\times$ & $\times$ & $\sqrt{ }$ & $\begin{array}{c}\text { Field, } \\
\text { Subject, } \\
\text { Geology }\end{array}$ & $\sqrt{ }$ & Subject & $\sqrt{ }$ & Subject \\
\hline
\end{tabular}

\section{Discussion}

Contemporary society is becoming increasingly aware of the interdisciplinary character of the fields in the natural sciences (e.g. Wake, 2008; Škoda \& Doulík, 2009). Geology as a science is a highly interdisciplinary field and the interpretation of geological information is directly dependent on other fields of science, especially physics, chemistry, astronomy, geography, mathematics and geoinformation systems. It is thus not surprising that allocation of the subject matter at the level of lower and higher elementary schools is the subject of numerous discussions (e.g. Fermeli et al., 2011; King, 2004; Pluskalová, 2004). Various countries have different approaches to teaching geology; however, geology is not taught as an independent subject almost anywhere. Integrated teaching of the natural sciences is not very common in the context of secondary education in Europe, including the Czech Republic, and the individual fields are taught as independent subjects. An integrated approach to teaching the natural sciences requires different professional and didactic preparation of future teachers (see e.g. Hejnová, 2011; Pluskalová, 2004). Thus, in the countries of Europe, geology is most frequently included in the subjects of Biology or Geography. Comparison of the curricular documents of selected countries with a similar level of economic development, following many years of a centralised schooling system with different trends in international evaluation, should reveal the positive and negative features of approaches towards natural science education. Simultaneously, it should provide subjects and recommendations for improving and increasing the attractiveness of teaching the natural sciences, especially geology in the Czech Republic. 


\subsection{COMPARISON OF CURRICULAR DOCUMENTS}

It follows from comparison of the curricular documents that the volume of the required subject matter is above average in the Czech Republic compared to the other analysed countries (see Tab. 4 as an example). A somewhat negative effect of a large amount of subject matter very frequently occurs in practice in duplication of teaching of some geological subjects at the lower secondary school level, where the same subject matter is discussed in various subjects or grades (e.g. the universe, formation and structure of the Earth). On the other hand, the flexibility of the Czech system is a favourable factor. It enables schools to move subject matter between the individual subjects and, where appropriate, to create new teaching subjects and integrate subject matter into them (including the possibility, e.g. of creating the separate subject of Geology) (Jeřábek et al., 2005). Nonetheless, this potential is insufficiently exploited and most school educational programmes exactly copy the assignment of subject matter set forth in the national curriculum. The possibility of freely assigning subject matter to the individual subjects in the framework of school educational programmes is based, amongst other things, on the mutual cooperation of teachers, interconnection of suitable subject areas and strengthening of the interdisciplinary approach to education. However, teachers often have no concept of the subject matter in other fields of the natural sciences. This attitude is completely contrary to the idea of an interdisciplinary approach to teaching (Wake, 2000, 2008), which should be reinforced.

The scope of geological subject matter in the Czech Republic is most similar to that in Estonia. The Polish curriculum corresponds to the Estonian curriculum in terms of the number of geological topics but the specific content is less. The Slovenian curriculum includes geology only sporadically. Slovenia and Poland approach the inclusion of geology in teaching through its integration into physical geography. The choice of educational content is quite logically completely determined by the local geology, but is not systematic. On the one hand, students are better able to remember examples and they are more illustrative for them but, on the other hand, the local emphasis prevents discussion of some important geological subjects or they are considered only marginally. The inclusion of geological content in the context of the Estonian curriculum is a sort of compromise between the explication of theoretical geological knowledge and specific examples of geological phenomena relating to the region of Estonia or Europe. Geological topics are first considered in general (this corresponds to the subject matter of Geology in the Czech curriculum); then the subject matter returns to the geological phenomena that correspond to the local geology (in parallel with the Polish and Slovenian curricula). The concept of the Estonian curriculum gives students the opportunity to connect their general knowledge with illustrative examples.

A great many surveys came to the conclusion that the low or decreasing interest of students in science is partly a consequence of its presentation as a collection of separated, out-of-context facts with little value, which are not related to everyday life and the personal experience of students (Aikenhead, 2005; Osborne, Simon \& Collins, 2003; Sjøberg, 2002). Thus, from the viewpoint of its illustrative capability, the Estonian exposition of geological subject matter and the simultaneous provision of comprehensive information seem most suitable. The volume of educational content is not reduced as a consequence of the local focus and theoretical information is simultaneously connected with what students can observe in the immediate surroundings. 


\subsection{Educational Content of Geology and Expected OUTCOMES}

All the curricular documents of the analysed countries have a general inadequacy in the incompleteness of the coverage of the key geological topics and, in some places, excessive vagueness in their definition. Specification of the educational content corresponds to classical teaching divided into the individual subjects with emphasis on learning the terminology, description of natural processes and classification of minerals, rocks and raw materials. The individual educational topics should be defined in relation to the most important geological processes, their physical or chemical nature and their mutual relationship. This is the only way that greater integration of knowledge can be achieved and skills acquired in the various disciplines. More general subjects should be supplemented by practical examples, where possible in areas familiar to students. Formulation of the outcomes should emphasise the ability to carry out simple analysis of phenomena and processes, where the student is capable of using the acquired knowledge to perform specific tasks. Outcomes should also encompass practical skills that the student can utilise in everyday life or his/her future employment, as well as theoretical observations which form his/her relationship to nature and the environment.

\subsection{RECOMMENDED TEACHING METHOdS}

A contemporary trend in education in the natural sciences and elsewhere is to introduce teaching methods based on critical thinking, independent work and individual observations, where the student develops his/her abilities irrespective of his/her natural talents. Teaching methods such as project teaching, experimentally oriented teaching and problem-based or complex tasks are generally conceived to maximise the individual development of each student within the framework of his/her abilities. This is motivating for the student and these methods are intended to make the content of the not-very-popular natural sciences accessible for students (Rocard et al., 2007). Wake (2008) based his work on a similar idea, according to which a student who is interested in a particular field can make a greater contribution to this field if (s)he is capable of properly employing the literature and technology, and of applying ideas and opinions.

However, the analysed countries have different approaches to requirements on the use of the above-mentioned teaching methods. While the Czech curriculum defines all the requirements only at the level of the educational area, Estonia, Slovenia and Poland recommend selected methods at the level of the specific teaching subjects. The Polish curriculum even contains a separate chapter dealing with the manner of implementation of methods suitable for teaching Geography. In addition, Estonia and Slovenia define the spheres of applied teaching. In this respect, the Czech curriculum is the briefest and tends to under-evaluate the recommendation of teaching methods suitable for education in the natural sciences. It would undoubtedly be more binding for teachers if the required teaching methods were fixed in the curriculum directly in connection with the subject they taught. Similarly, suggestions for implementation of these methods in teaching would simplify work for teachers, motivate them and help in achieving the defined expected outcomes. 


\subsection{INCORPORATION OF GEOLOGY - RECOMMENDATIONS FOR CZech EDUCATion}

The current inclusion of Geology with Biology in teaching the Natural Sciences (Biology) in the Czech Republic would seem to be obsolete in the present day. There is very little interpenetration of geological topics with biological topics. The connection of Geology with Physical Geography would undoubtedly be useful and would eliminate unnecessary duplicity; in addition Physical Geography directly describes and explains the shapes of the Earth, which are a consequence of endogenic or exogenic geological processes, and connects them with the environment, anthropogenic effects on the natural environment, non-renewable and renewable natural resources, agriculture, territorial planning and other disciplines. It thus has a far greater overlap with Geology than Biology. The fact that Geology is traditionally connected with Biology in the subject of Natural Science follows from the tradition of describing the connection between the development of non-living and living nature and probably also from the fact that Geography has a long tradition of teaching as a separate subject. The introduction of study programs for teaching geography together with geology in elementary schools would undoubtedly be facilitated by resolution of this problem. This combination is not yet available at universities in the Czech Republic. This is similar only to the combination of Natural Science with Environmental Studies. A similar connection would be useful at the level of education of teachers for secondary schools, where it is theoretically possible to study Geology together with Geography at Masaryk University in Brno, but this is not utilised very often.

\section{Conclusion}

Geology is not a very popular branch of science in the Czech Republic (e.g. Bicanová, 2013; Pařízková, 2015) and other European countries (Fermeli et al., 2011). It is a frequent complaint that there is too much theory and little connection to everyday life. While an above-average amount of information is provided to students according to the Czech curriculum, there is a lack of interconnection of the individual subject areas and scientific fields. The traditional combination of the geological sciences with biology does not facilitate such a close interconnection; these fields interpenetrate only in the area of palaeontology and related stratigraphy, the development of life, its evolution and the development of the relationship between non-living and living nature in the past. However, most geological processes tend rather to be controlled by the laws of physics and chemistry, whose exposition is lacking in the current explication of geology. In the Czech Republic, this problem already arises from the university preparation of pre-service teachers, which practically does not offer the possibility of studying the combined fields of geology and geography; this would seem to be a better approach to the preparation of teachers for the subject of Geology. Similarly, at the level of secondary education, the interconnection of these two subjects would undoubtedly contribute to better understanding of the connections between geological processes and their consequences, as studied by the geographic sciences. This change would probably lead to more effective and more attractive teaching. The modifications in the appearance of the curriculum in the Czech Republic should include expected outcomes encompassing, amongst other things, requirements on practical skills that the student can use in everyday life or his/her future employment. The learning content could be made more attrac- 
tive by including the requirement on the use of modern teaching methods, ideally supplemented by specific suggestions for implementation of these methods.

\section{ACKNOWLEDGEMENT}

This work has been supported by Charles University Research Centre No. UNCE/ HUM/024.

\section{REFERENCES}

Aikenhead, G.S. (2005). Research into STS science education. Educación Química, 16(3), 384-397. doi: 10.22201/fq.18708404e.2005.3.66101

Bicanová, L. (2013). Míra popularity geologických věd mezi žáky základních škol a víceletých gymnázií [Bakalářská práce]. České Budějovice: Jihočeská univerzita v Českých Budějovicích, Pedagogická fakulta.

Czerniak, C. M. (2014). Interdisciplinary science teaching. In S. Abell \& N. Lederman (Eds.), Handbook of research on science education (537-559). Mahwah, NJ: Lawrence Erlbaum Associates, Inc. doi: 10.4324/9780203097267.ch20

Erlingsson, C. \& Brysiewicz, P. (2017). A hands-on guide to doing content analysis. African Journal of Emergency Medicine, 7, 93-99. doi: 10.1016/j.afjem.2017.08.001

Euridyce. (2011). Science education in Europe: National policies, practices and research. Education, Audiovisual and Culture Executive Agency (EACEA P9 Eurydice). doi: $10.2797 / 7170$

Fermeli, G., Meléndez, G., Calonge, A., Dermitzakis, M., Steininger, F., Koutsouveli, A., Neto de Carvalho, C., Rodrigues, J., D'arpa, C. \& Patti, C. (2011). GEOSCHOOLS: Innovative teaching of geosciences in secondary schools and raising awareness on geoheritage in the society. In E. Fernández-Martínez \& R. Castaño de Luis (Eds.), Avances y retos en la conservación del Partimonio Geológico en España (120-124). Actas de la IX Reunión Nacional de la Comisión de Patrimonio Geológico (Sociedad Geológica de España), Léon, Universidad de Léon.

Lederman, N. G. \& Niess, M. L. (1997). Integrated, interdisciplinary, or thematic instruction? Is this a question or is it questionable semantics? School Science and Mathematics, 97(2), 57-58.

Hejnová, E. (2011). Integrovaná výuka přírodovědných předmětů na základních školách v českých zemích - minulost a současnost. Scied 2(2), 77-90.

Jeníková, K. (2017). Možnosti výuky geologie na gymnáziích. Diplomová práce. Praha: Univerzita Karlova.

Jeřábek, J. \& Tupý, J., et al. (2005). Manuál pro tvorbu školních vzdělávacích programů $v$ základním vzdèlávání. Praha: VÚP.

Jeřábek, J. \& Tupý, J., et al. (2017). Rámcový vzdělávací program pro základní vzdělávání, Praha: MŠMT. Available at http://www.msmt.cz/file/41216/

King, C. (2001). The response of teachers to new content in a national science curriculum: the case of the Earth-science component. Science Education, 85, 636-664. doi: $10.1002 /$ sce. 1030

King, C. (2004). Earth science at school level in the UK. ESEF (EW). Conference Improving the effectivenness of education resources for Earth science and industry, 19 October 2004, London. 
Meléndez, G., Fermeli, G. \& Koutsouveli, A. (2007). Analyzing geology textbooks for secondary school curricula in Greece and Spain: Educational use of geological heritage. Bulletin of the Geological Society of Greece, 40, 1819-1832. doi: 10.12681/bgsg.17143

Ministry of Education and Research. (2014). National curriculum for basic schools. Tallin.

Ministry of Education and Sport. (2011). White Paper on education in the Republic of Slovenia. Ljubljana.

Ministry of National Education. (2002). Core Curriculum for Pre-school and General Education. Warsaw.

OECD. (2018). PISA 2015 Results in Focus. Available at https://www.oecd.org/pisa/pisa-2015-results-in-focus.pdf, doi: 10.1787/9789264273856-en

Osborne, J., Simon, S. \& Collins, S. (2003). Attitudes towards science: a review of the literature and its implications. International Journal of Science Education, 25(9), 1049-1079. doi: 10.1080/0950069032000032199

Pařízková, Š. (2015). Průzkum zájmu o neživou přírodu u studenti̊ $Z \breve{S}$ a $S \breve{S}$ na Chrudimsku [Bakalářská práce]. České Budějovice: Jihočeská univerzita v Ceských Budějovicích, Pedagogická fakulta.

Pluskalová, J. (2004). Rámcový vzdělávací program a výuka geologie na základní škole a čtyřletém gymnáziu. E-pedagogium, 2005(2), 50-57.

Rocard, M., Csermely, P., Jorde, D., Lenzen, D., Walberg-Henrikson, H. \& Hermmo, U. (2007). Science education now: A renewed pedagogy for the future of Europe. Brussels: European Comission, Directorate-General for Research, Science, Economy and Society, Information and Communication Unit, Brussels. doi: 10.12691/education-3-7-14

Sjøberg, S., 2002. Science and technology education in Europe: Current challenges and possible solutions. Connect: UNESCO International Science, Technology E Environmental Education Newsletter, 27(3-4), 1-4. Available at http://unesdoc.unesco.org/images/0014/001463/146315e.pdf [Accessed 22 October 2018]

Škoda, J. \& Doulík, P. (2009). Vývoj paradigmat př́rodovědného vzdělávání.

Pedagogická orientace, 19(3), 24-44.

UNESCO (2012). International Standard Classification of Education ISCED 2011.

Quebec: UNESCO Institute for Statistic. ISBN 978-92-9189-123. Available at

http://uis.unesco.org/sites/default/files/documents/international-standard-classificationof-education-isced-2011-en.pdf.

Wake, M. H. (2000). Integrative biology as a framework for education and training. Biology International, 2000(39), 49-55.

Wake, M. H. (2008). Integrative biology: Science for the 21st century. BioScince, 58(4), 349-353. doi: 10.1641/B580410

TEREZA JEDLIČKOVÁ, tereza.jedlickova@natur.cuni.cz

Andrea Svobodová

VÁCLAV KACHLÍK

Charles University, Faculty of Science

Institute of Geology and Paleontology

Albertov 6, 12843 Prague, Czech Republic 